\title{
Legal Protection Towards Workers With Disabilities In Bali Province
}

\author{
Dewa Gede Sudika Mangku \\ Universitas Pendidikan Ganesha, Indonesia \\ dewamangku.undiksha@gmail.com
}

Ni Putu Rai Yuliartini

Universitas Pendidikan Ganesha, Indonesia

raiyuliartini@undiksha.ac.id

Submitted: Sep 28, 2021; Reviewed: Oct 26, 2021; Accepted: Nov 17, 2021

\begin{tabular}{l}
\hline Article's Information \\
\hline $\begin{array}{l}\text { keywords: } \\
\text { persons with disabilities; legal } \\
\text { protection; labour. }\end{array}$ \\
DOI
\end{tabular}

https://doi.org/10.25041/aelr.v2i2.2428

\section{Abstract}

Protection for workers, especially workers with disabilities, where the government recognises the safety and existence of workers with disabilities. Labour is part of the subject of employment which is considered able to do a job to produce goods or services to meet the needs of themselves and the community. When referring to the existing legislation, workers with disabilities' position in obtaining employment and the legal protection of the rights of workers with disabilities is the same as that of a non-disabled person. The Government of Indonesia has committed and seriousness to respect, protect, and fulfil the rights of persons with disabilities, which is ultimately expected to improve the welfare of people with disabilities. Therefore, the government is obliged to realise the rights contained in the convention through adjustment of legislation, including ensuring the persons with disabilities rights in all aspects of life. This article would like to find out the implementation of the legal protection towards the disabilities workers in Indonesia and what forms of legal protection should be implemented.

Therefore, this article will use research methods of legal normative and with statute approach, conceptual approach, and comparative approach. The researchers found that the legal 
protection towards disabilities is sufficiently proven by the regulation and policies that are applicable.

\section{A. Introduction}

\section{Background}

A large number of people with disabilities is a severe concern for the government, which continues to strive so that people with disabilities can be accepted to work in both government and private agencies that prioritise credibility and ability to carry out work regardless of physical factors.

Until now, legal protection to a person with disabilities' position, rights, obligations, and roles are supported through efforts regulated in Law No. 8 of 2016 concerning Persons with Disabilities, and various laws and regulations governing employment issues, national education, health, social welfare, road traffic and transportation, railways, shipping, aviation, and customs. ${ }^{1}$ However, protection measures alone are not sufficient, considering that the number of persons with disabilities continues to increase from time to time. ${ }^{2}$ This requires other means and efforts, mainly by providing facilities to obtain equal opportunities for persons with disabilities in all aspects of life and livelihood, especially in obtaining an education and work to realise their social welfare. $^{3}$

Regarding the rights of persons with disabilities to work, it is clearly and explicitly regulated in the Law of the Republic of Indonesia No. 8 of 2016 concerning Persons with Disabilities (Law of Persons with Disabilities) and Government Regulation of the Republic of Indonesia No. 43 of 1998 concerning Efforts to Improve the Social Welfare of Persons with Disabilities.

Protection of employment opportunities for workers with disabilities is also recognised in Law No. 13 of 2003 concerning Manpower, namely in Article 5, which states that "Every worker has equal opportunity without discrimination to get a job." Indonesia has also ratified the main instrument in international law that regulates the work rights of persons with disabilities, namely the UN Convention on the Rights of Persons with Disabilities (UNCRPD), concerning the rights of persons with disabilities (2006) and its Optional Protocol. Indonesia ratified the UN convention in November 2011 and promulgated Law No. 19 of 2011 concerning Ratification of the Convention on the Rights of Persons with Disabilities.

The government issued Government Regulation No. 43 of 1998 concerning Efforts to Improve the Social Welfare of Persons with Disabilities. It is regulated in Article 28, which reads: "Employers must employ at least 1 (one) person with a disability who meets the job requirements and job qualifications as a worker in the company for every 100 (one hundred) workers in the company". 4

Other regulations related to job training and placement of workers with disabilities, namely through the Decree of the Minister of Manpower and Transmigration of the Republic of Indonesia No. KEP-205/MEN/1999 concerning Job Training and Placement of Workers with Disabilities and issuing a Ministerial Circular No.01.KP.01.15.2002 concerning Placement of Workers with

\footnotetext{
${ }^{1}$ Alia Harumdani Widjaja, Winda Wijayanti, and Rizkisyabana Yulistyaputri, "Perlindungan Hak Penyandang

Disabilitas Dalam Memperoleh Pekerjaan Dan Penghidupan Yang Layak Bagi Kemanusiaan,” Jurnal Konstitusi 17, no. 1 (2020): 197, https://doi.org/10.31078/jk1719.

${ }^{2}$ Agustin Erna Rochmawati, "Perlindungan Hukum Bagi Tenaga Kerja Penyandang Disabilitas Dalam Pemenuhan HakHak Pekerja Berdasarkan Undang-Undang Nomor 13 Tahun 2003 Tentang Ketenagakerjaan Di Kabupaten Semarang,” Diponegoro Law Review 5, no. 2 (2016): 1-20, https://www.neliti.com/publications/19148/perlindungan-hukum-bagitenaga-kerja-penyandang-disabilitas-dalam-pemenuhan-hak\#cite.

${ }^{3}$ Budi Ardianto and Mochammad Farisi, "Perlindungan Hukum Bagi Penyandang Disabilitas Dalam Mendapatkan Pekerjaan Berdasarkan International Covenant On Economic Social And Cultural Rights 1966 Dan Undang-Undang Nomor 13 Tahun 2003 Tentang Ketenagakerjaan," Ganaya: Jurnal Ilmu Sosial Dan Humaniora 4, no. 1 (2021): 17992, https://jayapanguspress.penerbit.org/index.php/ganaya/article/view/1257.

${ }^{4}$ Rahayu Repindowaty Harahap and Bustanuddin, "Perlindungan Hukum Terhadap Penyandang Disabilitas Menurut Convention on the Rights of Persons with Disabilities (CRPD)," Jurnal Inovatif VIII, no. 1 (2015): 17-29, https://online-journal.unja.ac.id/index.php/jimih/article/view/2191.
} 
Disabilities in Companies.

But in reality, the number of companies in Indonesia, especially in Bali Province, that employs persons with disabilities can be said to be still minimal, be it government agencies, state companies, or private companies. ${ }^{5}$ Normatively, several legal instruments were born to protect the rights of persons with disabilities to work. Such as Law No. 13 of 2003 concerning Manpower which 'forbids' discrimination against persons with disabilities. Even Law No. 8 of 2016 concerning Persons with Disabilities further emphasises that right.

Opportunities to get equal status, rights, and obligations for persons with disabilities can only be realised if accessibility is available, namely a facility for persons with disabilities to achieve equal opportunities in obtaining equal positions, rights, and obligations. Therefore, necessary to make efforts to provide accessibility for persons with disabilities. With these efforts, it is hoped that persons with disabilities can be integrated into realising national development goals in general and improve the social welfare of persons with disabilities in particular.

Equality of opportunity is implemented through the provision of accessibility both by the government and the community, accompanied by efforts to increase public awareness and responsibility for persons with disabilities, which is an essential element in empowering persons with disabilities.

Based on the background of these problems, the problems are formulated as follows: First, how is the implementation of legal protection provided to workers with disabilities in the province of Bali. Second, what are the forms of legal protection provided for workers with disabilities in Bali Province?

\section{Research Method's}

The research method used in this research is normative legal research. The normative legal research uses primary, secondary and tertiary data, a statutory approach, a conceptual approach, and a comparative approach. All data were analysed using synthetic analysis. From the results of the synthesis analysis, conclusions are then taken as necessary.

\section{Theory Framework}

Law No. 13 of 2003 Article 1 No. 2 defines a workforce as everyone who can produce goods and/or services to meet their own needs and the community. Article 1 point 4 defines that an employer is an individual, entrepreneur, legal entity, or other entity that employs workers by paying wages or other forms of remuneration. This definition is somewhat general, but the meaning is broader because it can include all people who work for anyone, whether individuals, partnerships, legal entities, or other entities, by receiving wages or remuneration in any form.

According to Soepomo, labour protection is divided into 3 (three) types, namely:

a. Economic protection, namely the protection of workers in the form of sufficient income, includes if the workforce cannot work against their will.

b. Social protection, namely the protection of workers in occupational health insurance, freedom of association, and protection of the right to organise. ${ }^{6}$

c. Technical protection, namely the protection of workers in the form of work security and safety. $^{7}$

In the International Convention on the Rights of Persons with Disabilities and the Optional Protocol to the Convention (UN Resolution 61/106 13 December 2006), a person with a disability means any person who is unable to provide for himself, in whole or in part, the specific needs of

\footnotetext{
${ }^{5}$ Suharto Suharto, Pim Kuipers, and Pat Dorsett, "Disability Terminology and the Emergence of 'Diffability' in Indonesia," Disability \& Society 31, no. 5 (2016): 693-712, https://doi.org/10.1080/09687599.2016.1200014.

${ }^{6}$ Matthew Walsham et al., "Social Protection for People with Disabilities in Africa and Asia: A Review of Programmes for Low- and Middle-Income Countries," Oxford Development Studies 47, no. 1 (2019): 97-112, https://doi.org/10.1080/13600818.2018.1515903.

${ }^{7}$ Abdul Khakim, Pengantar Hukum Ketenagakerjaan Indonesia Berdasarkan UU No. 13 Tahun 2003 (Bandung: Citra Aditya Bakti, 2003).
} 
an individual and/or social life, as a result of their disability, whether congenital or not, in terms of physical or mental abilities. Juridically, the definition of persons with disabilities is regulated in Article 1 No. (1) of Law No. 8 of 2016 as follows: "Persons with Disabilities are any person who experiences physical, intellectual, mental, and/or sensory limitations in the long term which is interacting with the environment may experience obstacles and difficulties to participate fully and effectively with other citizens based on equal rights".

\section{B. Discussions}

\section{Legal Protection Application towards Workers with Disabilities in Bali Province}

People with disabilities right to work is regulated in Law No. 8 of 2016 on People with Disability (People with Disability Law) and Government Regulation No. 43 of 1998 on the Efforts to Improve Social Welfare of Persons with Disabilities.

Protection of employment opportunities for workers with disabilities is also recognised in Law No. 13 of 2003 concerning Manpower, namely in Article 5, which states that "Every worker has the same opportunity without discrimination to get a job". Indonesia has also ratified the main instrument in international law that regulates the work rights of persons with disabilities, namely the UN Convention on the Rights of Persons with Disabilities (UNCRPD), concerning the rights of persons with disabilities (2006) and its Optional Protocol. Indonesia ratified the UN convention in November 2011 and promulgated Law No. 19 of 2011 concerning Ratification of the Convention on the Rights of Persons with Disabilities. ${ }^{8}$

The government issued Government Regulation No. 43 of 1998 concerning Efforts to Improve the Social Welfare of Persons with Disabilities. It is regulated in Article 28, which reads:" Employers must employ at least 1 (one) person with a disability who meets the job qualification requirements as a worker in the company for every 100 (one hundred) workers in his company".

Lower regulations related to job training and placement of workers with disabilities, namely through the Decree of the Minister of Manpower and Transmigration of the Republic of Indonesia No. KEP-205/MEN/1999 concerning Job Training and Placement of Workers with Disabilities and issuing a Ministerial Circular No.01.KP.01.15.2002 concerning Placement of Workers with Disabilities in Companies. ${ }^{9}$

The number of companies in Indonesia that employ people with disabilities is minimal, whether government agencies, state companies, or private companies. Whereas ideally, every company must employ at least one person with a disability who meets the job requirements and job qualifications for every 100 workers in his company. Normatively, several legal instruments were born to protect the rights of persons with disabilities to work. Such as Law No. 13 of 2003 concerning Manpower which "forbids" discrimination against persons with disabilities.

Opportunities to get equal status, rights, and obligations for persons with disabilities can only be realised if accessibility is available, namely a facility for persons with disabilities to achieve equal opportunities in obtaining equal positions, rights, and obligations. Therefore, it is necessary to make efforts to provide accessibility for persons with disabilities. By these efforts, it is hoped that persons with disabilities can be integrated into realising national development goals in general and improve the social welfare of persons with disabilities in particular.

Implementing efforts to improve social welfare, which is carried out among others through equal opportunities for persons with disabilities, is essentially a shared responsibility of the

\footnotetext{
${ }^{8}$ I Gede Siwananda Putra A.K, I Ketut Markeling, and I Nyoman Darmadha, "Perlindungan Hukum Terhadap Pekerja Penyandang Disabilitas Di Yayasan Puspadi Bali," Kertha Semaya : Journal Ilmu Hukum 7, no. 8 (2019): 1, https://doi.org/10.24843/km.2019.v07.i08.p04.

${ }^{9}$ Renuka Nardodkar et al., "Legal Protection of the Right to Work and Employment for Persons with Mental Health Problems: A Review of Legislation across the World," International Review of Psychiatry 28, no. 4 (2016): 375-84, https://doi.org/10.1080/09540261.2016.1210575.
} 
government, the community, families, and persons with disabilities themselves. Therefore, it is hoped that all of these elements will play an active role in making it happen. By this equal opportunity, it is hoped that persons with disabilities can carry out their social functions to integrate through communication and interaction naturally in social life. ${ }^{10}$

The reality that occurs and is faced by persons with disabilities is not as good as those regulated by law and other regulations. Data from the Ministry of Manpower in 2010 shows that only $23.6 \%$ of people with disabilities are working, and $76.4 \%$ are not working. Of $23.6 \%$, who worked as civil servants/police/military $1.3 \%, 0.1 \%$ worked as State-owned Enterprises/Regional-Owned Enterprises employees, $1 \%$ worked in the livestock/fishery sector, $8.5 \%$ worked as traders/entrepreneurs, $39.9 \%$ worked in the agricultural sector, $15.1 \%$ worked in the service sector, and $32.7 \%$ worked as farm labourers/casual laborer. On the other hand, those working in companies as workers/labourers in an employment relationship are $2.1 \%$ (source Ministry of Manpower 2010). And this is also supported by the fact that only $3.1 \%$ of companies in Indonesia employ workers/labourers with disabilities. This shows that most people with disabilities are not working.

\section{Forms of Legal Protection Provided for Workers with Disabilities in Bali}

A sense of security, both mentally and physically, from interference and various threats from any party. Legal protection is to protect human rights that others have harmed, and this protection is given to the community so that they can enjoy all the rights granted by law. In other words, legal protection is various legal remedies that law enforcement officials must provide to provide legal protection. ${ }^{11}$

Protection for workers with disabilities according to Law No. 13 of 2003, among others, broadly includes:

\section{a. Wage Protection and Labor Social Security}

Wages play a significant role and are the hallmark of an employment relationship. It is even said that wages are the primary goal of a worker who works for another person or legal entity. That's why the government deals with this wage issue through various policies as outlined in the legislation. ${ }^{12}$

Every worker has the right to earn a decent income for humanity. To realise a decent income, the government establishes protection with wages for workers. The government carries out the realisation of decent income by setting minimum wages based on decent needs. Wage arrangements are determined based on an agreement between employers and workers. ${ }^{13}$

Wages are one of the most critical aspects of the protection of workers or labourers. This is explicitly explained in Article 88 paragraph (1) of Law No. 13 of 2003 that every worker or labourer has the right to earn an income that meets a decent living for humanity. According to Article 1 No. 30 of Law No. 13 of 2003, what is meant by wages is the rights of workers received and expressed in the form of money as compensation from the entrepreneur or employer to the worker or labourer determined and paid according to a work agreement or laws and regulations, including allowances for workers or labourers and their families for a job and or service that has

\footnotetext{
${ }^{10}$ Shirli Werner and Roni Holler, "Attitudes toward Guardianship, Social Work Goals, and Perspectives of Disability among Social Work Students,” Disability and Rehabilitation 42, no. 5 (2020): 712-21, https://doi.org/10.1080/09638288.2018.1508510.

${ }^{11}$ Monica Pinilla-Roncancio, María Goméz-Castillo, and Eilionoir Flynn, "Data and Human Rights for Persons with Disabilities: The Case of Deprivation of Liberty," The International Journal of Human Rights 24, no. 6 (2020): 828-49, https://doi.org/10.1080/13642987.2019.1690462.

12 Pamungkas Satya Putra, "Aksesibilitas Perlindungan Hukum Bagi Tenaga Kerja Penyandang Disabilitas Di Kabupaten Karawang," Mimbar Hukum - Fakultas Hukum Universitas Gadjah Mada 31, no. 2 (2019): 205, https://doi.org/10.22146/jmh.44200.

${ }^{13}$ B Siswanto Sastrohadiwiryo, Manajemen Tenaga Kerja Indonesia : Pendekatan Administrasi Dan Operasional (Jakarta: Bumi Aksara, 2003).
} 
been or will be performed.

Based on the Regulation of the Minister of Manpower No. PER-01/MEN/1999 jo. The Decree of the Minister of Manpower and Transmigration No. KEP-226/MEN/2000 covers the area of application of the minimum wage covering: provincial minimum wage or Upah Minimum Provinsi (UMP) valid in all districts or cities in 1 (one) province; district or city minimum age or Upah Minimum Kabupaten atau Kota (UMK) valid in 1 (one) district or city.

Labor social security is a form of protection given to workers and their families against various risks experienced by workers. The workforce in Indonesia is vast, around 100 million people, and will continue to grow by more than 2 (two) per cent per year. Therefore, the Social Health Insurance Administration Body or Badan Penyelenggara Jaminan Sosial (BPJS) organised the current form of protection, maintenance, and improvement of welfare. Workers' Social Security Protection is now embodied in Law No. 40 of 2004 concerning the National Social Security System and Law No. 24 of 2011 concerning BPJS, consisting of BPJS Health and BPJS Employment.

And BPJS now includes BPJS Health and BPJS Employment which is a continuation of the Social Security for Workers, which PT Social Security previously implemented. What is meant by Labor Social Security is a protection for workers in the form of providing health insurance and compensation in the form of money as a partial replacement of lost or reduced income and services. These losses result from events or conditions experienced by workers in the form of work accidents, illness, pregnancy, maternity, old age, and death.

\section{b. Occupational Health and Safety}

In Article 86 paragraph (1), letter (a) of Law No. 13 of 2003 concerning occupational health is one of the rights of workers or labourers. Employers are obliged to implement it systematically and integrate it with the company management system. Occupational health efforts aim to protect workers or labourers from achieving optimal work productivity by preventing accidents and occupational diseases, controlling workplace hazards, health promotion, treatment, and rehabilitation.

Thus, the objectives of occupational health are: To protect workers from the risk of work accidents; To improve the health status of workers/labourers; So that workers or labourers and the people around them are guaranteed their health; Ensuring that production is maintained and used safely and efficiently. About occupational health, every entrepreneur is obliged to carry out the following provisions:

\section{Working Hours}

Working hours as referred to in Article 77 Paragraph (1) of Law No. 13 of 2003 which include: a.7 (seven) hours 1 (one) day and 40 (forty) hours 1 (one) week for 6 (six) working days in 1 (one) week; or b.8 (eight) hours 1 (one) day and 40 (forty) hours 1 (one) week 5 (five) working days in 1 (one) week. For the rest of the working time, it is possible to work overtime for a maximum of 3 hours in 1 day. Therefore, the entrepreneur is obliged to pay overtime wages following the Minister of Manpower No. 1022004.

\section{Working Leaves}

Pengusaha juga wajib memberikan waktu istirahat dan cuti kepada pekerja atau buruh :

a. Weekly leave 1 (one) day for 6 (six) working days in 1 (one) week or 2 (two) days for 5 (five) working days in 1 (one) week; b. Rest between working hours, at least half an hour after working for 4 (four) hours continuously, and the rest time does not include working hours; c. Annual leave, at least 12 (twelve) working days after the worker or labourer in question has continuously worked for 12 (twelve) months; d. An extended leave of at least 2 (two) months in the seventh and eighth year for 1 (one) month each for workers or labourers who have worked for 6 (six) years continuously at the company. The said worker or labourer is no longer entitled to his annual leave in the current 2 (two) years and is valid for every multiple of 6 (six) years of service. 
Occupational health is a way for workers to do decent work for humanity. ${ }^{14}$ It is not only aimed at entrepreneurs who want to exploit workers/labourers but also at the workers/labourers themselves.

\section{Working Safety}

With the advancement of industrialisation, mechanisms, and modernisation, there is also an increase in the intensity of operational work and workers' workplace in most rights. This requires the intensive mobilisation of labour from the workers. This can cause fatigue, lack of attention, and loss of balance, which could cause accidents. It is necessary to understand the need for proper work safety knowledge. Furthermore, with advanced regulations, excellent and realistic security will be achieved, which is an essential factor in providing a sense of peace, activity, and enthusiasm for work for the workforce concerned, in this case, it can improve the quality of work increase productivity and work productivity.

Occupational safety is safety related to machines, work equipment, materials and processing processes, workplace foundations and environment, and ways of doing work. The object of work safety is all workplaces, whether on the land, ground, on the water's surface, in the water, or the air. In Article 1 of Law No. 1 of 1970 concerning Occupational Safety, it is explained that there are 3 (three) elements: a place where work is carried out for a business; There are workers who work there; There is a work hazard in that place.

Meanwhile, Article 6 of Law No. 1 of 1970 explains that work accidents are related to work relations and accidents that occur on the way from home to work and return home by road or reasonable to pass.

\section{c. Legal Protection for Workers with Disabilities to Form and Become a Member of a Labor Union}

Trade unions/labour unions are organisations formed from, by, and for workers/labourers both in and outside the company. These unions are free, open, independent, democratic, and responsible for fighting for, defend and protecting the rights and interests of workers/labourers and improving the welfare of workers/labourers and their families.

Legal protection related to the rights of workers/labourers to form and become members of trade unions/labour unions is contained in Article 104 of Law No. 13 of 2003. Article 104 paragraph 1 states that: "Every worker/laborer has the right to form and become a member of a trade union/labor union". Workers/labourers who are members of trade unions/labour unions have the right to manage and account for the organisation's finances, including strike funds. The provisions in Article 104 of Law No. 13 of 2003 align with Law No. 21 of 2000 concerning Trade Unions/Labour Unions, particularly Article 5 paragraph 1, which has the same sound as article 104 paragraph 1 of Law No. 13 of Law 2003. Even the legal protection for workers/labourers in Law No. 21 of 2000 is manifested in facilitating the formation of unions/labour unions, where at least 10 (ten) workers/labourers have the right to form a trade union/labour union. ${ }^{15}$

\section{d. Protection of the Basic Rights of Workers / Laborers to Negotiate with Employers}

The Manpower Law regulates the working relationship between Workers/labourers and entrepreneurs, which means regulating the interests of individuals. The working relationship that regulates between workers/labour and entrepreneurs contains the rights and obligations of the parties. The definition of rights and obligations is always reciprocal between one another. The rights of workers or labourers are the obligations of entrepreneurs, and vice versa, the rights of employers

\footnotetext{
${ }^{14}$ I Wayan Tika Tambunan, I Nyoman Putu Budiartha, and Ni Made Puspasutari Ujianti, "Perlindungan Hukum Bagi Pekerja Penyandang Disabilitas Pada PT. Sumber Alfaria Trijaya,” Jurnal Interpretasi Hukum 1, no. 2 (2020): 116-21, https://doi.org/10.22225/juinhum.1.2.2447.116-121.

15 Annisa Fitria, "Perlindungan Hukum Terhadap Pekerja Atau Buruh," Lex Jurnalica (Journal of Law) 15, no. April (2018): 325, https://ejurnal.esaunggul.ac.id/index.php/Lex/article/view/2612/2250.
} 
are also the obligations of workers/labourers. To make this happen, Law no. 13 of 2003 concerning Manpower in article 106 has regulated an institution which is a forum for communication and negotiation for workers/labourers with employers, namely the existence of a Bipartite institution. This Bipartite Institution functions as a forum for communication and consultation regarding employment matters in a company. The membership of the Bipartite Institution consists of entrepreneurs and elements of workers/labourers who are democratically appointed by workers/labourers to represent the interests of the workers/labourers in the company concerned. ${ }^{16}$ The Bipartite Institution is also the first institution to resolve disputes between workers/labourers and employers. Law No. 13 of 2003 concerning Manpower in article 107 also regulates other rights to negotiate in a Tripartite Cooperation institution which functions almost the same as a Bipartite institution. This Tripartite Institution provides considerations, suggestions, and opinions to the government and related parties, including workers/labourers and employers, in formulating policies and solving employment problems. The membership of the Tripartite Cooperation Institution consists of elements of the government, employers' organisations, and trade unions/labour unions representing workers/labour. The Tripartite Cooperation Institutions consist of the National, Provincial, and Regency/City Tripartite Cooperation Institutions and the National, Provincial, and Regency/City Tripartite Cooperation Institutions.

TABLE 1.1

The Protection That Should Given to Disabilities Workers

\begin{tabular}{|c|c|c|}
\hline Protection & Regulations & Explanation \\
\hline Health Protection & $\begin{array}{c}\text { Article } 86 \text { Paragraph (1) Law } \\
\text { No. } 13 \text { of } 2003\end{array}$ & $\begin{array}{l}\text { In this regulations explain that } \\
\text { every workers should have the } \\
\text { occupational protection on } \\
\text { health. Where it plays huge } \\
\text { roles because disabilities is } \\
\text { more prone for having a } \\
\text { disease so it's really necessary } \\
\text { to have health protection on } \\
\text { them. On this case } \\
\text { implementing BPJS to } \\
\text { disabilities workers are needed }\end{array}$ \\
\hline Wage Protection & $\begin{array}{c}\text { Article } 88 \text { Paragraph (1) Law } \\
\text { No. } 13 \text { of } 2003\end{array}$ & $\begin{array}{l}\text { The income for workers or } \\
\text { laborers should meet the } \\
\text { decent living standard based } \\
\text { on province they living on }\end{array}$ \\
\hline Legal Protection & $\begin{array}{l}\text { Article } 104 \text { Law No. } 13 \text { of } \\
2003 \text { and Law No.21 of } 2000\end{array}$ & $\begin{array}{l}\text { The protection on legal itself } \\
\text { isn't only on legal assistance } \\
\text { but also the protection on their } \\
\text { rights for gathering and share } \\
\text { opinion. }\end{array}$ \\
\hline
\end{tabular}

${ }^{16}$ S Suhartoyo, “"Perlindungan Hukum Bagi Buruh Dalam Sistem Hukum Ketenagakerjaan Nasional,” Adm Law Gov 2, no. 2 (2019): 326-36, https://doi.org/10.14710/alj.v2i2.326-336. 
On the table above it explain that there's three main rights that author think it should cover for the protection on the disabilities workers. Where those three right are health protection that covered by BPJS, wage protection, and legal protection.

\section{Conclusion}

From the overall analysis and discussion, it can be concluded that: Legal protection for workers with disabilities in Indonesia at the policy and regulatory level is sufficient, which is marked by various applicable laws and regulations, starting from the Constitution, Law Laws, Government Regulations to Ministerial Decrees and even Regional Regulations. However, in practice, legal protection for workers with disabilities has not been appropriately implemented, especially concerning the obligation of every company or agency to employ 1 (one) person with disabilities in every company that employs every 100 people. Protection on wages, welfare, social security for workers; protection of occupational safety and health; Legal protection to form and become members of a trade union/labour union; Protection of the fundamental rights of workers/labourers to negotiate; with the entrepreneur.

For example, social security for workers is a form of protection given to workers and their families against various risks experienced by workers. The labour force in Indonesia is tremendous, around 100 million people, and will continue to grow by more than 2 (two) per cent per year.

\section{Bibliography}

\section{A. Journal}

Ardianto, Budi, and Mochammad Farisi. "Perlindungan Hukum Bagi Penyandang Disabilitas Dalam Mendapatkan Pekerjaan Berdasarkan International Covenant On Economic Social And Cultural Rights 1966 Dan Undang-Undang Nomor 13 Tahun 2003 Tentang Ketenagakerjaan." Ganaya: Jurnal Ilmu Sosial Dan Humaniora 4, no. 1 (2021): 179-92. https://jayapanguspress.penerbit.org/index.php/ganaya/article/view/1257.

Fitria, Annisa. "Perlindungan Hukum Terhadap Pekerja Atau Buruh." Lex Jurnalica (Journal of Law) 15, no. April (2018): 325. https://ejurnal.esaunggul.ac.id/index.php/Lex/article/view/2612/2250. Harahap, Rahayu Repindowaty, and Bustanuddin. "Perlindungan Hukum Terhadap Penyandang Disabilitas Menurut Convention on the Rights of Persons with Disabilities (CRPD)." Jurnal Inovatif VIII, no. 1 (2015): 17-29. https://onlinejournal.unja.ac.id/index.php/jimih/article/view/2191.

Nardodkar, Renuka, Soumitra Pathare, Antonio Ventriglio, João Castaldelli-Maia, Kenneth R. Javate, Julio Torales, and Dinesh Bhugra. "Legal Protection of the Right to Work and Employment for Persons with Mental Health Problems: A Review of Legislation across the World." International Review of Psychiatry 28, no. 4 (2016): 375-84. https://doi.org/10.1080/09540261.2016.1210575. Pinilla-Roncancio, Monica, María Goméz-Castillo, and Eilionoir Flynn. "Data and Human Rights for Persons with Disabilities: The Case of Deprivation of Liberty." The International Journal of Human Rights 24, no. 6 (2020): 828-49. https://doi.org/10.1080/13642987.2019.1690462.

Putra A.K, I Gede Siwananda, I Ketut Markeling, and I Nyoman Darmadha. "Perlindungan Hukum Terhadap Pekerja Penyandang Disabilitas Di Yayasan Puspadi Bali." Kertha Semaya : Journal Ilmu Hukum 7, no. 8 (2019): 1. https://doi.org/10.24843/km.2019.v07.i08.p04.

Putra, Pamungkas Satya. "Aksesibilitas Perlindungan Hukum Bagi Tenaga Kerja Penyandang Disabilitas Di Kabupaten Karawang." Mimbar Hukum - Fakultas Hukum Universitas Gadjah Mada 31, no. 2 (2019): 205. https://doi.org/10.22146/jmh.44200.

Rochmawati, Agustin Erna. "Perlindungan Hukum Bagi Tenaga Kerja Penyandang Disabilitas Dalam 
Pemenuhan Hak-Hak Pekerja Berdasarkan Undang-Undang Nomor 13 Tahun 2003 Tentang Ketenagakerjaan Di Kabupaten Semarang.” Diponegoro Law Review 5, no. 2 (2016): 1-20. https://www.neliti.com/publications/19148/perlindungan-hukum-bagi-tenaga-kerjapenyandang-disabilitas-dalam-pemenuhan-hak\#cite.

Suharto, Suharto, Pim Kuipers, and Pat Dorsett. "Disability Terminology and the Emergence of 'Diffability' in Indonesia." Disability \& Society 31, no. 5 (2016): 693-712. https://doi.org/10.1080/09687599.2016.1200014.

Suhartoyo, S. ""Perlindungan Hukum Bagi Buruh Dalam Sistem Hukum Ketenagakerjaan Nasional." Adm Law Gov 2, no. 2 (2019): 326-36. https://doi.org/10.14710/alj.v2i2.326-336.

Tambunan, I Wayan Tika, I Nyoman Putu Budiartha, and Ni Made Puspasutari Ujianti. "Perlindungan Hukum Bagi Pekerja Penyandang Disabilitas Pada PT. Sumber Alfaria Trijaya." Jurnal Interpretasi Hukum 1, no. 2 (2020): 116-21. https://doi.org/10.22225/juinhum.1.2.2447.116121.

Walsham, Matthew, Hannah Kuper, Lena Morgon Banks, and Karl Blanchet. "Social Protection for People with Disabilities in Africa and Asia: A Review of Programmes for Low- and MiddleIncome Countries." Oxford Development Studies 47, no. 1 (2019): 97-112. https://doi.org/10.1080/13600818.2018.1515903.

Werner, Shirli, and Roni Holler. "Attitudes toward Guardianship, Social Work Goals, and Perspectives of Disability among Social Work Students." Disability and Rehabilitation 42, no. 5 (2020): 712-21. https://doi.org/10.1080/09638288.2018.1508510.

Widjaja, Alia Harumdani, Winda Wijayanti, and Rizkisyabana Yulistyaputri. "Perlindungan Hak Penyandang Disabilitas Dalam Memperoleh Pekerjaan Dan Penghidupan Yang Layak Bagi Kemanusiaan.” Jurnal Konstitusi 17, no. 1 (2020): 197. https://doi.org/10.31078/jk1719.

\section{B. Books}

Khakim, Abdul. Pengantar Hukum Ketenagakerjaan Indonesia Berdasarkan UU No. 13 Tahun 2003. Bandung: Citra Aditya Bakti, 2003.

Siswanto Sastrohadiwiryo, B. Manajemen Tenaga Kerja Indonesia : Pendekatan Administrasi Dan Operasional. Jakarta: Bumi Aksara, 2003.

\section{Regulations}

1945 Constitution of the Republic of Indonesia

Law No. 13 of 2003 concerning Manpower

Law No. 19 of 2011 concerning Ratification of the Convention on the Rights of Persons with

Disabilities

Law No. 8 of 2016 concerning Persons with Disabilities

Decree of the Minister of Manpower and Transmigration of the Republic of Indonesia No. KEP205/MEN/1999 concerning Job Training and Placement of Persons with Disabilities

Government Regulation of the Republic of Indonesia No. 43 of 1998 concerning Efforts to Improve Social Welfare of Persons with Disabilities

Ministerial Circular Letter No. 01.KP.01.15.2002 concerning Manpower Placement of Persons with Disabilities in the Company 